\title{
Estudo do processo de lixiviação controlada da escória de aciaria em extrator soxhlet visando emprego em pavimentos
}

\author{
Study of controlled leaching process \\ of steel slag in soxhlet extractor \\ aiming employment in pavements
}

Kíssyla Ávila Costa ${ }^{1}$, Antônio Carlos Rodrigues Guimarães ${ }^{2}$, Marcelo de Miranda Reis ${ }^{2}$, Claudeny Simone Alves Santana ${ }^{2}$

\footnotetext{
${ }^{1}$ Instituto Militar de Engenharia - Praça Gen. Tibúrcio, nº80, Urca - CP: 22290270, Rio de Janeiro - RJ. e-mail: kissyla.avila@gmail.com.br

${ }^{2}$ Instituto Militar de Engenharia - Praça Gen. Tibúrcio, nº80, Urca - CP: 22290270, Rio de Janeiro - RJ. e-mail: cap-guimarães@hotmail.com; marceloreis@ime.eb.br ; cl_deny@yahoo.com.br
}

\begin{abstract}
RESUMO
Este trabalho aborda a caracterização das propriedades físicas, químicas e mecânicas da escória de aciaria para emprego como agregado antes e após ensaio de lixiviação controlada em extrator Soxhlet. O material foi caracterizado antes de passar por processo de estabilização (escória virgem) e após lixiviação controlada em períodos distintos de 24, 56, 96, 120 horas. A escória foi submetida, em laboratório, a uma simulação de precipitação em equipamento Soxhlet visando avaliar suas propriedades físicas, químicas e mecânicas após cada período. O estudo do processo de lixiviação em escória de aciaria buscou compreender a influência do processo de lavagem no comportamento da escória. A caracterização física se deu por meio dos ensaios tradicionais de agregados graúdos, a caracterização química através dos ensaios de Microscopia Eletrônica por Varredura (MEV) completada pela análise de Espectroscopia de Energia Dispersiva (EDS) e Difração de Raio-X, a caracterização mecânica por meio de ensaios de expansão normatizado e adaptado. A amostra virgem, sem receber processo de estabilização por lixiviação controlada, apresentou resultados satisfatórios na caracterização física quando comparada a agregados convencionais, a caracterização química comprovou ser uma escória de aciaria com elevados teores de $\mathrm{CaO}, \mathrm{MgO}$ e $\mathrm{FeO}$, enquanto a caracterização mecânica demonstrou que, apesar do grau de expansibilidade da escória ser baixo pelos padrões atuais, este não deve ser desconsiderado em obras para pavimentação. Após lixiviação controlada a escória não apresentou perda significativa de suas propriedades físicas. Quanto aos ensaios mecânicos de expansão houve redução no potencial de expansibilidade após os períodos de lixiviação. Conclui-se que o processo de lixiviação em extrator Soxhlet é de importância no estudo das propriedades da escória de aciaria, uma vez que contemplando vários dias de lixiviação houve redução do potencial de expansão, característica limitante no uso da escória de aciaria em pavimentação.
\end{abstract}

Palavras chaves: Escória de aciaria, caracterização, pavimentação.

\section{ABSTRACT}

This work addresses the characterization of physical, chemical and mechanical properties of steel slag as an alternative aggregation before and after leaching testing controlled Soxhlet extractor. The material it was characterized before going through the natural leaching process and after controlled leaching in different periods of $24,56,96,120$ hours. The steel slag was subjected in the laboratory to simulate the precipitation in Soxhlet equipment to evaluate its physical, chemical and mechanical properties after each period described. The study of the process of leaching in steel slag searched to understand the influence of the washing process in a slag behavior in such a process. The physical characterization occurred through traditional testing of coarse aggregates, the chemical characterization through the testing of Scanning Eletron Microscopy (SEM) completed by Dispersive Spectroscopy Energy (DSE) and X-ray diffraction and the mechanical characterization through testing of standardized expansion and adapted. The sample virgin, without receiving process of stabilization by controlled leaching, showed satisfactory results in the physics characterization when com- 
pared to conventional aggregates, the chemical characterization proved to be a steel slag with high contents of $\mathrm{CaO}, \mathrm{MgO}$ and $\mathrm{FeO}$, the mechanical characterization demonstrated that, although the degree of expansibility of the slag is low demonstrated that this should not be disregarded in the paving work. After controlled leaching the steel slag showed no significant loss of its physical properties. As the mechanical testing of expansion had decreased the potential of expansibility after leaching periods. It is concluded that the leaching process in a Soxhlet extractor is of importance in the study the properties of steel slag, once covering several days of leaching was reduced potential for expansion, limiting feature in the use of steel slag for paving.

Keywords: Steel slag, characterization, paving.

\section{INTRODUÇÃO}

A questão ambiental é motivo de grandes preocupações de forma geral, sendo que a exploração dos recursos naturais e a geração de resíduos em grandes proporções, principalmente na construção civil, tem estimulado a comunidade científica para o estudo do reaproveitamento destes resíduos [31].

O reaproveitamento de resíduos é mais desejável que a disposição em aterros, pois permite a redução da extração de matérias primas, preservando os recursos naturais e zelando pela qualidade ambiental [31].

A indústria siderúrgica é grande geradora de resíduos. De acordo com a Associação Brasileira de Metalurgia e Materiais - ABM [1], em 2007 a produção mundial e brasileira de aço bruto foi de 1.344,3 e 33,8 milhões, respectivamente. Na produção do aço são gerados resíduos que giram em torno de $450 \mathrm{~kg}$ a $500 \mathrm{~kg}$ por tonelada de aço bruto produzido. Deste total, as escórias representam mais de $70 \%$.

Devido à grande quantidade de escória siderúrgica gerada, observa-se o esforço do setor siderúrgico para encontrar alternativas para sua reciclagem e reutilização em diversos setores, como a construção civil [28].

A utilização da escória de aciaria como agregado para pavimentação é consagrada e tem sido objeto de estudo de diversos pesquisadores. Geyer [20] avaliou o potencial de utilização da escória de aciaria como adição de concreto para construção civil e comprovou que a mesma não alterou significativamente o desempenho do concreto armado, Rohde [27] verificou a viabilidade da utilização da escória para base e sub-base de pavimentos e confirmou seu emprego como agregado para tais camadas e que os valores de módulo de resiliência (MR) foram superiores aos de agregados convencionais, Pedrosa [26] utilizou-se de misturas de CBUQ contendo escórias para verificar o uso deste agregado e constatou resultados satisfatórios onde os valores de MR da mistura asfáltica foram de 5.833MPa e 8.649MPa próximos, e até superiores, aos de agregados tradicionais. Freitas e Motta [19] empregaram a escória de aciaria em mistura asfáltica de módulo elevado e comprovaram que os MR's destas são semelhantes aos do agregado convencional, com valores de MR superiores a 8.000MPa. Outros trabalhos como de Mansuero [24], Castelo Branco [9], Marcaccini [25], Tavares [34] e Silva [30] corroboram a viabilidade da utilização da escória de aciaria em camadas de pavimentos.

Alguns estudos internacionais também utilizaram a escória de aciaria como agregado para pavimentação. Jia-chen Xi et al [23] estudaram o efeito da granulometria da escória como agregado para mistura asfáltica com a avaliação do processo de beneficiamento, após a combinação de vários processos de britagem da escória comprovaram, por meio de ensaios de agregados convencionais, maior estabilidade das características físicas da escória, ou seja, redução do teor de finos e redução na abrasão Los Angeles. Ahmedzade e Sengoz [4] avaliaram o desempenho da escória de aciaria como agregado graúdo em misturas asfálticas e também indicaram valores superiores ao agregado convencional analisado. Sorlini et al [33] investigaram o potencial de utilização da escória de aciaria em mistura asfáltica com foco no processo de expansão do material, quanto ao comportamento mecânico as misturas asfálticas contendo escória apresentaram resultados semelhantes aos agregados naturais, porém, observaram que um tempo de cura de 2-3 meses deveria ser respeitado.

Tais pesquisas utilizaram escórias ditas curadas ou indicaram algum período de estocagem para a estabilização volumétrica, ou seja, estas deveriam ficar expostas a um longo período de disposição em pátio, submetidas, eventualmente, a jatos de água. Em geral um processo sem maiores controles de qualidade e que demandam de tempo e grandes áreas.

No presente artigo buscou-se estudar as características físicas, químicas e estruturais da escória de aciaria antes e após processo de lixiviação controlada em extrator Soxhlet, visando emprego em pavimentação com realização de ensaios tradicionais de caracterização de agregados graúdos e até que sua composição residual química tenha uma quantidade limite aceitável de elementos expansivos. Nesta pesquisa não foram avaliadas as características mecânicas de misturas asfálticas contendo agregado de escórias, uma vez que diversos estudos já comprovaram sua eficiência para utilização em camadas de pavimentos, o objeto deste 
trabalho é o processo de lixiviação em laboratório para redução dos componentes responsáveis pelo processo de expansão e consequente diminuição do tempo de estabilização deste material na pilha de estocagem.

\section{FUNDAMENTAÇÃO TEÓRICA}

\subsection{Escória de aciaria}

Durante a produção do aço são gerados diversos subprodutos, dentre eles, as escórias siderúrgicas. Existem dois tipos de escórias siderúrgicas produzidas em larga escala de acordo com o processo produtivo utilizado: (a) as escórias de alto-forno, que são resultantes da fusão do minério de ferro para a obtenção do ferro-gusa, com alto teor de carbono; (b) as escórias de aciaria que resultam da produção do aço, podendo ser obtidas em fornos elétricos e conversores a oxigênio, processo conhecido como Lins-Donawitz (LD) ou Blast Oxygen Furnace (BOF) [34].

A escória é vasada ainda quente no pátio e necessita ser submetida ao resfriamento antes da britagem. De acordo com Alves [3], o resfriamento da escória líquida pode ocorrer de duas maneiras: (i) de forma lenta e natural, formando um material com estrutura cristalina e (ii) de forma rápida com jatos de água, que originam, em sua maioria, materiais com composição vítrea.

Segundo Baltazar [7], a escória de aciaria provém de uma oxidação seletiva de várias impurezas. Este processo é obtido por meio da adição de fundentes, principalmente o óxido de cálcio e fluorita, à carga metálica para a formação da escória. A carga metálica fundida e refinada é processada por meio das reações de oxidação das impurezas do aço.

A escória de aciaria tem funções no processo produtivo do aço de servir como receptor para os constituintes indesejáveis do banho metálico, agir como reservatório oxidante, controlar o suprimento de oxigênio da atmosfera para o metal e agir como barreira física dificultando a transferência para o metal de gases como o hidrogênio, oxigênio e enxofre [7].

De acordo com Campos [8], a escória de aciaria pode conter elementos tais como $\mathrm{SiO} 2, \mathrm{CaO}, \mathrm{Al} 2 \mathrm{O} 3$, $\mathrm{MgO}, \mathrm{MnO}, \mathrm{Fe} 2 \mathrm{O} 3$ e $\mathrm{Cr} 2 \mathrm{O} 3$ em sua composição.

Castelo Branco [9] relata que a hidratação dos compostos $\mathrm{CaO}$ e $\mathrm{MgO}$ livres é a principal responsável pelo processo de expansão das escórias no curto e longo prazo. O acréscimo da concentração da cal $(\mathrm{Ca}(\mathrm{OH}) 2$ das escórias de aciaria está diretamente relacionado com o aumento da expansibilidade das mesmas, bem como a elevação da temperatura e da quantidade de espécies no estado livre. Outros fatores em menor escala também influenciam na expansão da escória como a corrosão do ferro metálico ( $\mathrm{Fe} 0)$ e mudanças nas formas alotrópicas do $2 \mathrm{CaO}-\mathrm{SiO} 2$.

Baltazar [7] afirma que a reação entre a água e o $\mathrm{CaO}$ livre presente na escória de aciaria forma compostos volumetricamente menores, porém, as partículas hidratadas crescem em uma orientação preferencial produzindo pressão ao seu redor ocorrendo o processo de expansão. $\mathrm{O} \mathrm{MgO}$ se hidrata mais lentamente causando instabilidade ao longo prazo e está diretamente ligado ao tamanho dos cristais, ou seja, cristais pequenos tendem a se hidratar mais rapidamente e podem causar ruptura, enquanto os cristais grandes (formados por resfriamento lento) se hidratam lentamente e causam grandes expansões.

A expansibilidade da escória de aciaria é o principal limitante de sua utilização em obras de pavimentação causando defeitos no pavimento em forma de trincas e/ou "vulcões". Para se utilizar os agregados de escória de aciaria em pavimentação, a mesma deve passar por um processo de cura, onde os óxidos livres estejam hidratados e a expansão volumétrica esteja estabilizada

\subsection{Lixiviação controlada - Soxhlet}

De acordo com Heck [21], a lixiviação é a dissolução de um ou mais minerais pela água ou por uma solução aquosa do agente lixiviante. O processo de lixiviação é executado com o objetivo de separação, ou seja, na remoção de minerais ou impurezas de modo a separá-los de uma grande massa.

Em extrator Soxhlet a lixiviação contínua permite a separação dos constituintes de uma amostra, a uma temperatura abaixo do ponto de ebulição da água, evitando a sua decomposição térmica [22].

A extração contínua pode tornar o processo de extração mais prático, econômico, seguro e com maior rendimento do material a ser extraído.

Os extratores Soxhlet são equipamentos utilizados também na avaliação de alterabilidade acelerada de rochas, para recuperação de ligante ou para obtenção de óleos vegetais. Nesse ensaio a amostra é submetida à lixiviação em ciclos de umedecimento e secagem em temperaturas que vão até a ebulição da água. Tal equi- 
pamento viabiliza o controle da variação de temperatura, precipitação e altura da coluna de solução, proporcionando o monitoramento da solução de lixiviação [29].

O equipamento é constituído por manta aquecedora, balão, tubo extrator e tubo condensador, conforme mostra a Figura 1. Dentro do balão, coloca-se a solução de lixiviação, que pode ser água destilada, acetona, éter dependendo do material que se pretende lixiviar. Esta solução pode ser monitorada e se necessário, trocada durante o ensaio. A manta aquece a solução e produz vapor, que é conduzido ao topo do extrator por meio do tubo condutor de vapor. O vapor é condensado no tubo condensador, localizado no topo do tubo extrator.

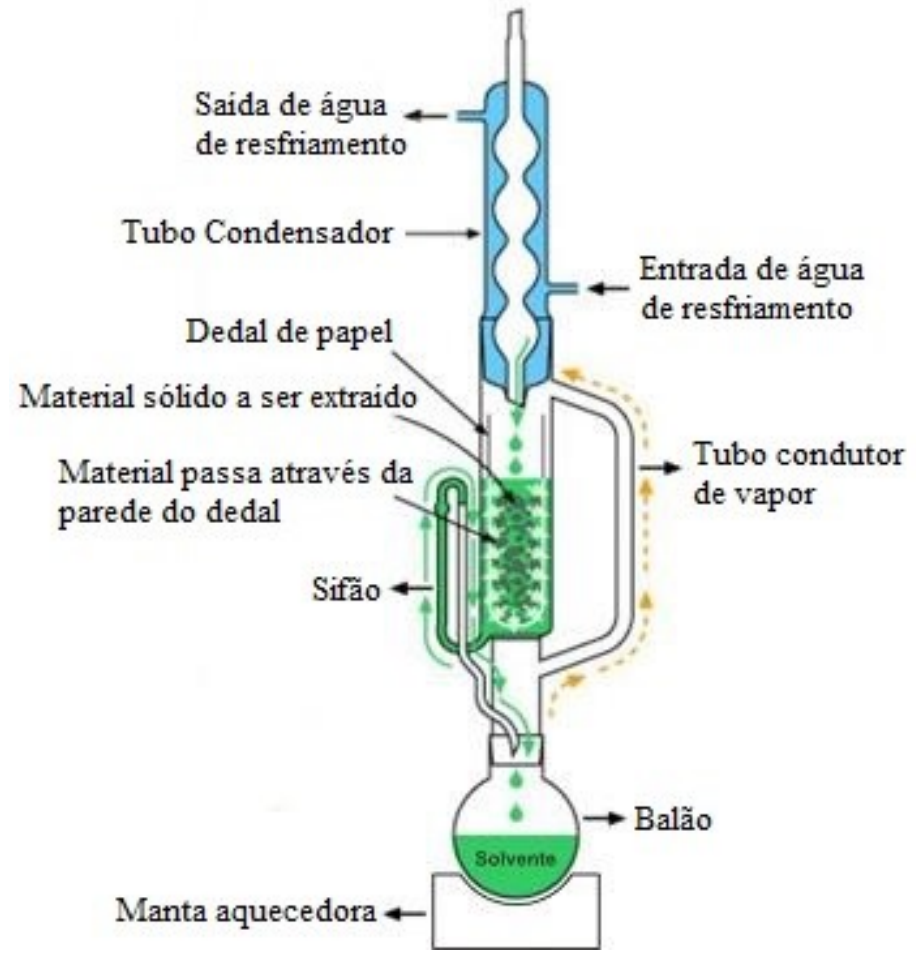

Figura 1: Equipamento Soxhlet convencional.

Cabe ressaltar que o extrator Soxhlet utiliza soluções de percolação em altas temperaturas, em torno de $60^{\circ} \mathrm{C}$ a $80^{\circ} \mathrm{C}$. A principal dificuldade deste ensaio é a reprodução das condições reais de campo durante os testes, uma vez que as condições experimentais não irão representar aquelas que ocorrem na natureza. Entretanto, tal equipamento promove a alteração do material ensaiado de forma acelerada e pode revelar a dissolução de alguns minerais durante o intemperismo químico [32]. No caso das escórias de aciaria o intemperismo químico pode ocorrer de forma natural por mais de um ano em pátios de estocagem.

\section{MATERIAIS E MÉTODOS}

\subsection{Materiais}

A escória de aciaria estudada nesta pesquisa é comercializada pela Harsco Metals, sendo oriunda da Companhia Siderúrgica nacional (CSN), localizada na cidade de Volta Redonda/RJ, conforme Figura 2, tendo sido fornecido material considerado virgem. 


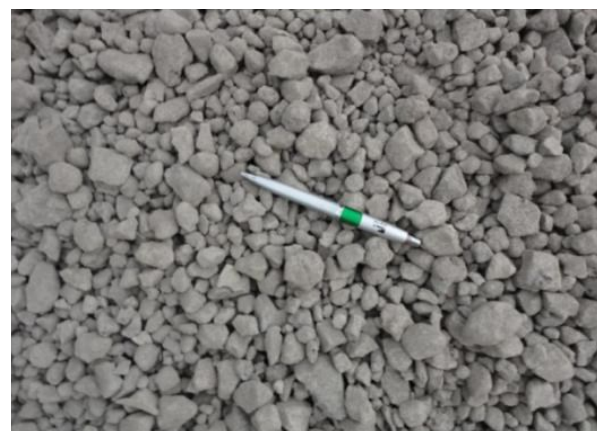

Figura 2: Escória de aciaria utilizada nesta pesquisa (Agregado 01)

Para a pesquisa foi escolhida a granulometria passante na peneira de malha $19 \mathrm{~mm}$ e retido na peneira de malha 4,75 mm. Essa granulometria foi determinada, pois agregados com dimensões maiores que $19 \mathrm{~mm}$ poderiam forçar e danificar a parede do tubo extrator do equipamento Soxhlet, por ser de vidro, e dimensões menores que 4,8 mm para que não houvesse a colmatação do sifão do equipamento, devido a presença de uma camada de material fino na superfície do agregado de escória de aciaria.

Essa espécie de limpeza superficial da amostra tende a interferir nos resultados de forma conservativa, aumentando o tempo de lixiviação necessário para minimização do potencial de expansão da escória, haja vista a menor superfície específica do agregado graúdo.

\subsection{Equipamento}

A pesquisa foi realizada com a amostra de escória de aciaria, submetida ao processo de lixiviação por meio do extrator Sohxlet no Laboratório de Ligantes e Misturas Betuminosas do Instituto Militar de Engenharia IME, conforme Figura 4.

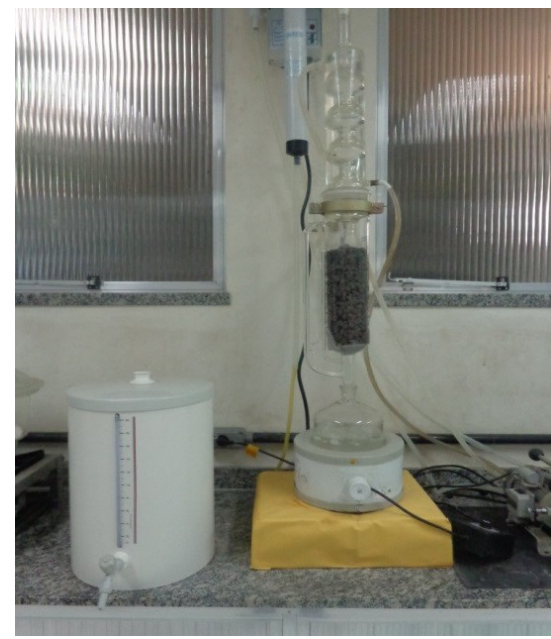

Figura 3: Extrator Soxhlet utilizado nesta pesquisa.

O equipamento Soxhlet do IME possui um balão volumétrico com capacidade de $2000 \mathrm{ml}$, um tubo extrator com capacidade de $4000 \mathrm{ml}$ (ou $3 \mathrm{~kg}$ do agregado de escória de aciaria) e um tubo condensador. O laboratório também conta com um destilador para o fornecimento do solvente (água destilada) utilizado na lixiviação da escória de aciaria desta pesquisa.

\subsection{Metodologia}

Cerca de $3 \mathrm{~kg}$ de material, passante na peneira de $19 \mathrm{~mm}$ e retido na peneira de 4,75 $\mathrm{mm}$, foi colocado no interior do tubo extrator, sem lavagem prévia, onde a escória de aciaria passou pelo processo de lixiviação contínua que visou simular a precipitação da água da chuva. O material foi lixiviado por períodos de 24, 56, 96 e 120 horas, cada período contemplou 8 horas de lixiviação por dia, sendo interrompido o ciclo de lixiviação durante a noite. 
Devido à grande quantidade de ensaios de caracterização da escória lixiviada no extrator Soxhlet houve a necessidade de ser colocada uma nova amostra por período de lixiviação dentro do tubo extrator e optouse por retirar a amostra a cada intervalo. Assim cada amostra de 3,0 kg é inteiramente utilizada nos ensaios de caracterização subsequentes, de modo que as idades de lixiviação (24, 56, 96 e 120 horas) se referem a amostras diferentes.

Verificou-se que durante a lixiviação, dentro do equipamento, ocorrem três situações distintas de lixiviação (Figura 4): a primeira condição $(\mathrm{C} 1)$, onde a temperatura do agregado varia de $70^{\circ} \mathrm{C}$ a $85^{\circ} \mathrm{C}$ e sofre sempre o estado de lixiviação; a segunda condição (C2) onde a temperatura do agregado está entre $50^{\circ} \mathrm{C}$ a $65^{\circ} \mathrm{C}$ e está sujeito a variação no nível da solução; e a terceira condição (C3) em que o agregado está em temperatura inferior a $40^{\circ} \mathrm{C}$ e sempre submerso na solução de lixiviação.

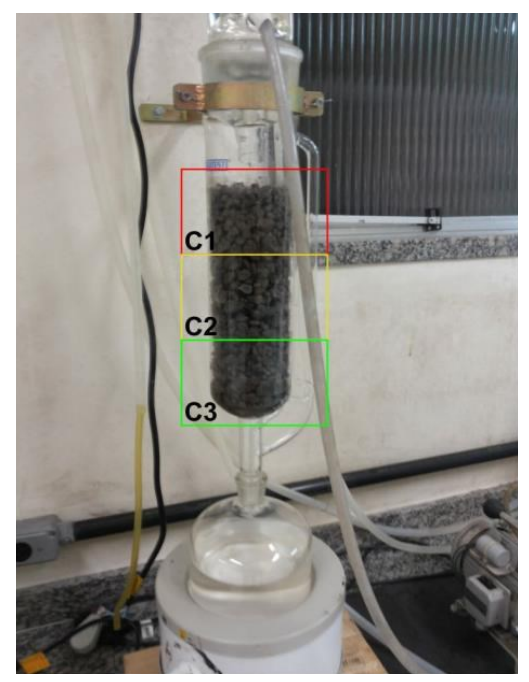

Figura 4: Equipamento com as condições C1, C2 e C3.

Após cada período de lixiviação no extrator Soxhlet, todo o material foi retirado do equipamento Soxhlet e separado e analisado de forma visual de acordo com cada condição descrita (C1, C2, e C3). A Figura 5 apresenta um exemplo da separação do material após o período de 24 horas de lixiviação.

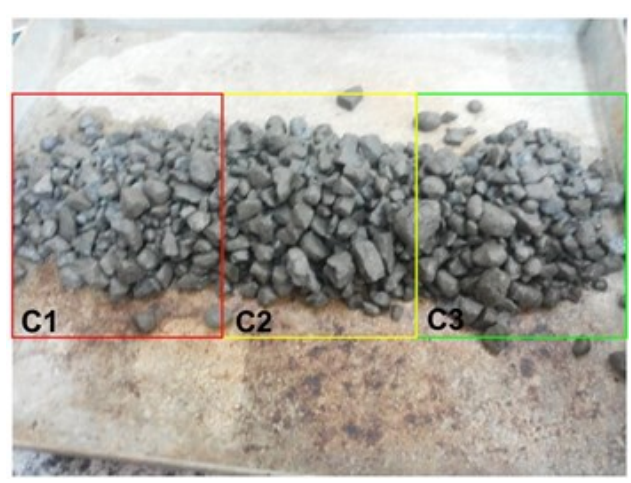

Figura 5: Separação da escória de aciaria após 24 horas de lixiviação.

Após separação, foi perceptível de maneira visual que em algumas amostras houve oxidação por ferro (mudança de coloração do material) e deterioração de partículas. Em cada condição (C1, C2, e C3) observada no extrator Soxhlet e após cada período de Lixiviação (24, 56, 96 e 120 horas) as amostras foram caracterizadas novamente através de ensaios tradicionais.

$\mathrm{Na}$ escória virgem foram realizados ensaios de granulometria, densidade real e aparente, absorção, impacto tetron, abrasão Los Angeles, MEV e EDS e potencial de expansão.

Na escória lixiviada em extrator Soxhlet após cada condição e período foram realizados ensaios de densidade real e aparente, absorção, impacto treton, MEV e EDS e potencial de expansão. Não foi possível a realização de ensaios de granulometria e Abrasão Los Angeles devido a limitação de quantidade do material dentro do equipamento Soxhlet. 


\section{RESULTADOS E DISCUSSÃO}

\subsection{Caracterização da escória de aciaria virgem}

A escória de aciaria estudada nesta pesquisa possui uma granulometria dita comercial, no padrão da empresa Harsco Metals. O material coletado (Agregado 01) foi propositalmente selecionado num intervalo granulométrico de interesse para esta pesquisa.

$\mathrm{O}$ agregado coletado para esta pesquisa apresenta granulometria aberta (Figura 6) e não se enquadrou nos limites da composição de agregado graúdo da norma ABNT NBR 7211 [2] para agregados de concreto, bem como não se enquadrou nos limites granulométricos da especificação ACERITAC para pavimentação com escória de aciaria. Dessa forma, o material com granulometria comercial não poderá ser empregado como substituto total dos agregados pétreos em misturas asfálticas.

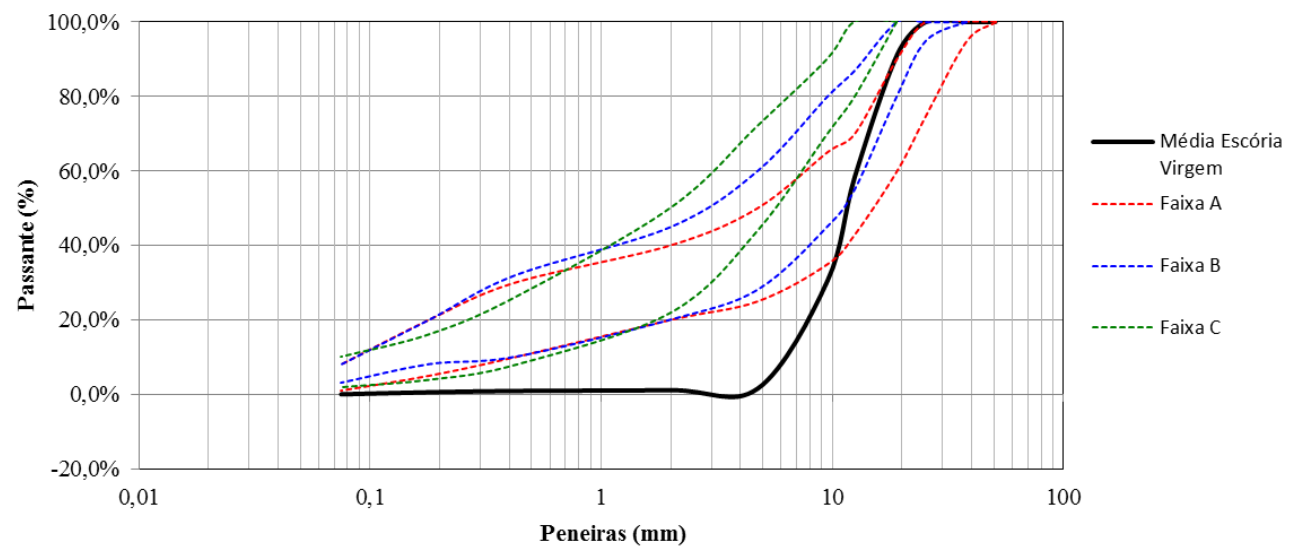

Figura 6: Distribuição granulométrica por peneiramento da escória de aciaria virgem.

Os resultados de densidade real e aparente, absorção, abrasão Los Angeles, impacto Treton e durabilidade estão apresentados na Tabela 1, onde tais resultados são comparados com os valores recomendados em normas para agregados convencionais e para escória de aciaria.

Tabela 1: Caracterização física da escória de aciaria virgem deste estudo.

\begin{tabular}{|c|c|c|c|c|c|}
\hline \multirow{2}{*}{ Parâmetros Analisados } & \multirow{2}{*}{ Média } & \multicolumn{2}{|c|}{ Agregados Convencionais } & \multicolumn{2}{|c|}{ Escória de Aciaria } \\
\hline & & Especificação & Normas & Especificação & Normas \\
\hline Densidade Real $\left(\mathrm{g} / \mathrm{cm}^{3}\right)$ & 3,38 & - & & - & \\
\hline $\begin{array}{l}\text { Massa específica aparente } \\
\left(\mathrm{g} / \mathrm{cm}^{3}\right)\end{array}$ & 3 & - & & $3,0-3,5-$ & \\
\hline Massa unitária $\left[\mathrm{kg} / \mathrm{dm}^{3}\right]$ & 1,7 & - & & $1,5-1,7$ & DNER - ES \\
\hline Absorção [\%] & 3,5 & $\leq 2$ & DNER- ME 195/97 & $\leq 2$ & $262 / 94$ \\
\hline Abrasão Los Angeles [\%] & 24,9 & $\leq 65$ & DNER- ME 035/94 & $25 \%$ & \\
\hline Ensaio Tréton [\%] & 8,31 & $\leq 60$ & DNER- ME 399/99 & - & \\
\hline Perda durabilidade [\%] & 4,4 & $\leq 12$ & DNER- ME 089/94 & $0-5$ & \\
\hline
\end{tabular}

A partir dos dados da Tabela 1 observa-se que a escória de aciaria deste estudo atendeu a quase todos os parâmetros analisados. O único valor acima dos limites normatizados foi a absorção com 3,5\%, porém, este valor é o esperado em escória de aciaria, conforme descrito em diversas literaturas como Chesner et al. [10] que relatam valores de absorção da escória de aciaria acima de 3\%, Rohde [27] que encontrou valores entre $1,8 \%$ e $2,9 \%$, enquanto Jia-chen Xi et al [23] encontrou valores de absorção variando entre 1,3\% e $1,5 \%$. 
$\mathrm{O}$ valore de densidade real encontrado na escória de aciaria desta pesquisa foi de $3,38 \mathrm{~g} / \mathrm{cm}^{3}$ e pode ser comparado com diversas literaturas: Rohde [27] encontrou valores de densidade real variando de 3,44 a $3,52 \mathrm{~g} / \mathrm{cm}^{3}$; Tavares [34] verificou em seu estudo valor de densidade real de 3,39 g/ $\mathrm{cm}^{3}$; e Castelo Branco [9] encontrou valores de densidade real de $3,30 \mathrm{~g} / \mathrm{cm}^{3}$.

Foi realizado o ensaio de durabilidade na escória de aciaria, e seu resultado ficou dentro dos limites normatizados. Após este ensaio a amostra foi encaminhada para o Microscópio Eletrônico de Varredura $(\mathrm{MEV})$ a fim de verificar a microestrutura do material após ataque do sulfato de sódio anidro (Figura 7).

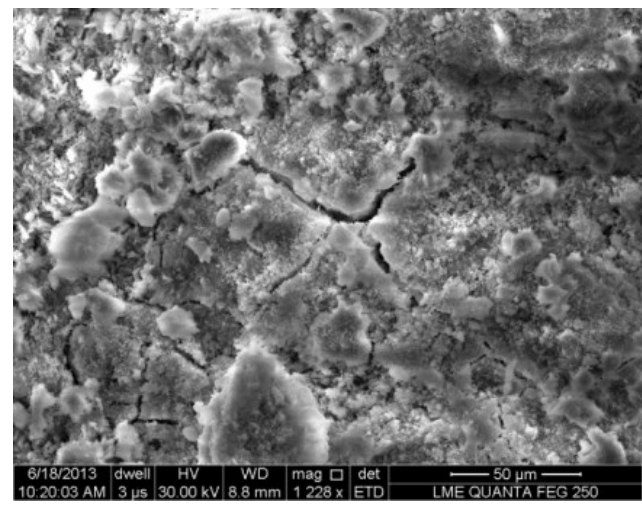

Figura 7: Micrografia da escória de aciaria virgem após ensaio de durabilidade com magnitude de aumento de 1228x.

O ensaio de durabilidade na escória de aciaria virgem resultou em uma perda de massa de 4,4\%, portanto inferior ao limite de $12 \%$ e 5\% nas normas especificadas na Tabela 1. Entretanto, a imagem obtida em MEV, mostrada na Figura 7, indicou microfissuras no agregado após este ensaio, porém apenas observadas com aumento de 1.228 vezes. A variação nos resultados dos ensaios tradicionais de agregado graúdo é esperada quando se trata de escória de aciaria, devido a heterogeneidade do material por se tratar de um coproduto da fabricação do aço.

Foi realizado ensaio de Espectrometria de Energia Dispersiva (EDS) para verificação a composição química (Figura 8) e difração de raios-X para análise a composição química e estrutura cristalina da escória de aciaria virgem (Figura 9).

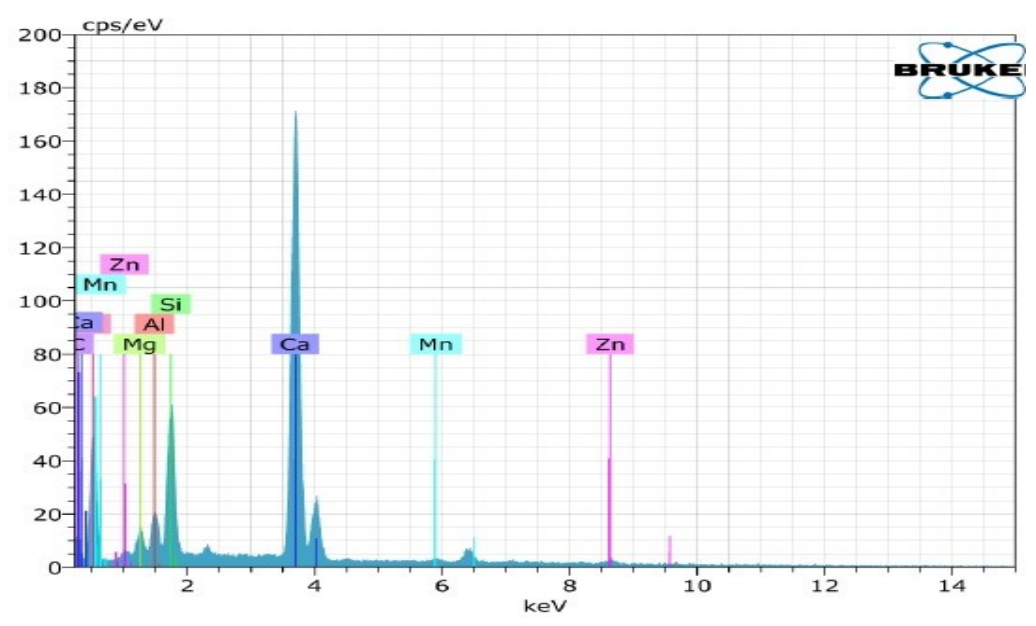

Figura 8: Composição química da escória de aciaria virgem desta pesquisa obtida por EDS.

A composição química da escória de aciaria por EDS comprovou ser uma escória de conversor a oxigênio devido à elevada concentração de $\mathrm{CaO}$. Também foram encontrados óxidos de magnésio, manganês, ferro e sílica. 


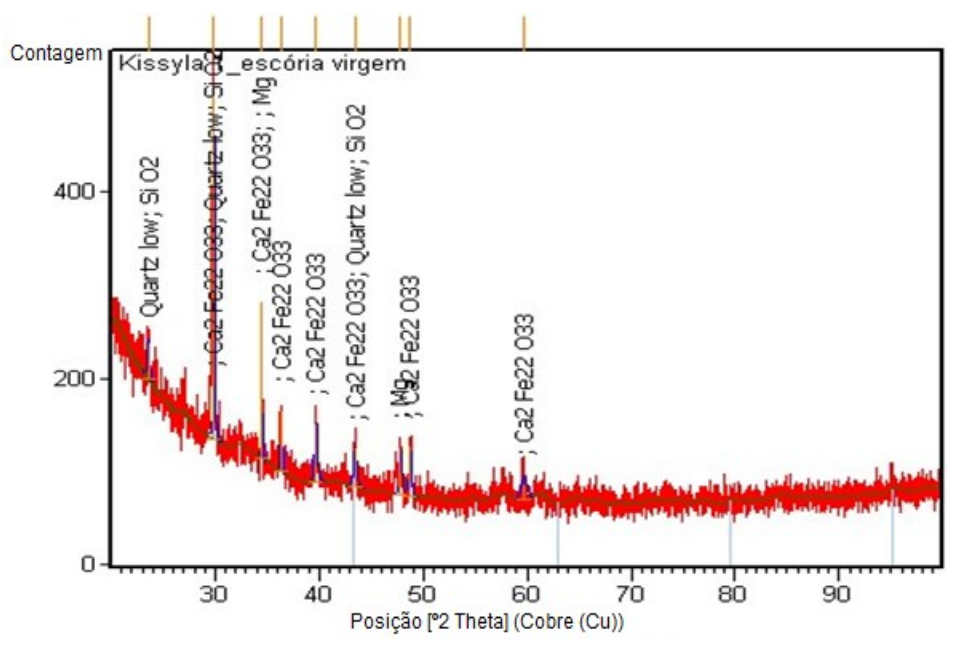

Figura 9: Composição química da escória de aciaria virgem desta pesquisa obtida por difração de raios-X.

Os elementos químicos encontrados no EDS foram observados também na difração de raios-X. As principais estruturas cristalinas encontradas foram o compósito na fase ferrito (Ca2Fe22O33) e a Sílica (SiO2).

O ensaio de expansão da escória virgem foi realizado conforme método de ensaio DNER ME 113 [13]. No entanto, devido à limitação na quantidade de material, inserida no equipamento Soxhlet, foi realizado uma adaptação do método utilizando-se o molde Mini-MCV com $49 \mathrm{~mm}$ de diâmetro. A escória de aciaria foi peneirada antes do ensaio a fim de eliminar a presença de finos ao redor do agregado de escória de aciaria, procedimento que seria o mais próximo da lixiviação em extrator Soxhlet. O resultado do ensaio de expansão é apresentado na Figura 10 e foi observado um valor de 1,4\%.

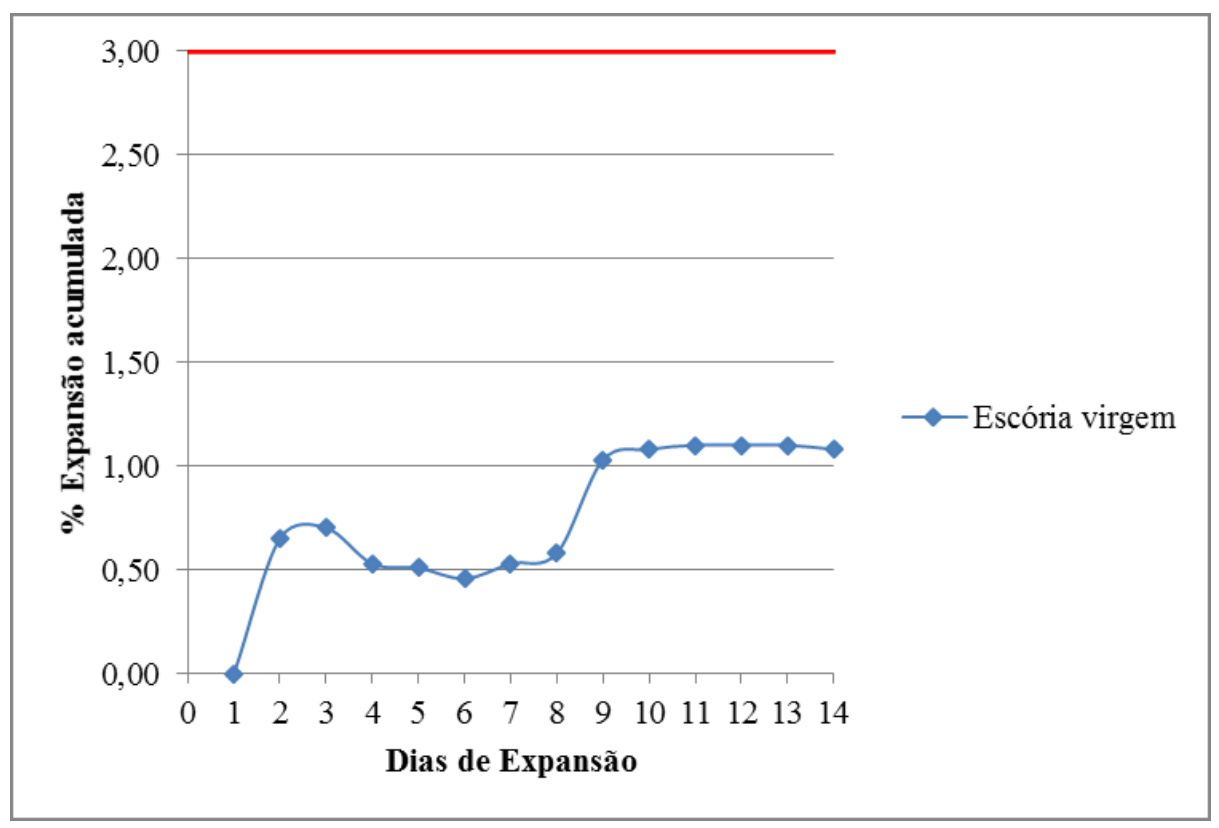

Figura 10: Porcentagem de expansão da escória virgem.

Trata-se de um valor relativamente baixo para a condição virgem, sendo inferior ao limite da DNER 262 (1994). Porém, uma análise crítica da norma resulta na interpretação de que o valor limite - de 3\% - é muito elevado, haja visto que o limite estabelecido para bases de pavimento é de apenas $0,5 \%$, de acordo com a norma ASTM D 4792 [5] que descreve o procedimento para o ensaio do potencial de expansão e a ASTM D 2940 [6] estabelece o limite de expansão da escória de aciaria. O valor de expansão da norma americana é 
inferior a norma brasileira o que indica que esse limite deve ser estudado.

\subsection{Caracterização da escória de aciaria lixiviada}

Dentro do extrator Soxhlet cada amostra de 3,0kg de escória de aciaria foi lixiviada durante os períodos de 24 , 56, 96 e 120 horas respectivamente, com ciclos contínuos de 8 horas de lixiviação por dia sendo interrompidos durante o período noturno. O processo de lixiviação ocorreu por meio da passagem da água destilada pelo agregado. Após cada período a escória de aciaria lixiviada foi caracterizada e os resultados comparados com a escória de aciaria virgem.

Foi observado de forma visual que durante a lixiviação o agregado apresentou trincas e algumas partículas pulverizaram (Figura 11), principalmente na condição C1 (parte superior do equipamento), onde ocorre temperatura elevada.

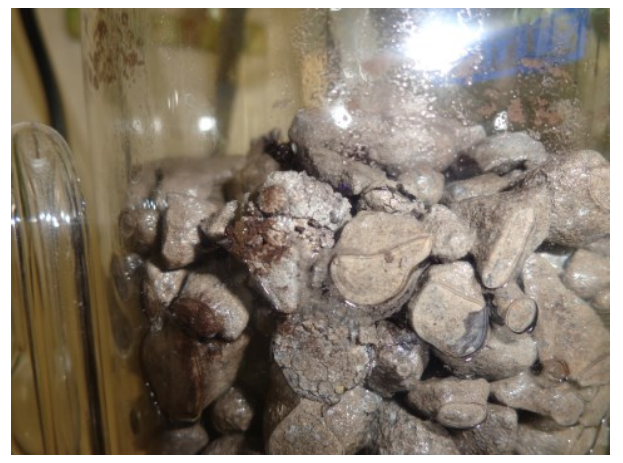

Figura 11: Vista lateral dos agregados de escória de aciaria dentro do equipamento Soxhlet apresentando expansão.

A caracterização física da escória de aciaria contemplou os ensaios de densidade real e aparente, absorção e massa específica, impacto treton e durabilidade. Os resultados foram expressos por meio de tabelas e gráficos. Em um mesmo gráfico representam-se cada condição analisada $(\mathrm{C} 1, \mathrm{C} 2$ e C3) durante os períodos estudados $(24,56,96,120$ horas) de lixiviação.

Os resultados de densidade real são apresentados na Tabela 2 e Figura 12.

Tabela 2: Variação da densidade real do agregado de escórias em função do tempo de lixiviação.

\begin{tabular}{|c|c|c|c|c|c|c|}
\hline \multirow{2}{*}{$\begin{array}{c}\text { Densidade } \\
\text { Real da escó- } \\
\text { ria de aciaria } \\
\text { virgem } \\
\left(\mathrm{g} / \mathrm{cm}^{3}\right) \\
\end{array}$} & \multicolumn{2}{|c|}{ C1 - Lixiviado Superior } & \multicolumn{2}{|c|}{ C2 - Lixiviado Intermediário } & \multicolumn{2}{|c|}{ C3 - Lixiviado Fundo } \\
\hline & $\begin{array}{c}\text { Horas de } \\
\text { Lixiviação }\end{array}$ & $\begin{array}{c}\text { Densidade } \\
\text { Real } \\
\left(\mathrm{g} / \mathrm{cm}^{3}\right)\end{array}$ & $\begin{array}{l}\text { Horas de Li- } \\
\text { xiviação }\end{array}$ & $\begin{array}{c}\text { Densidade } \\
\text { Real } \\
\left(\mathrm{g} / \mathrm{cm}^{3}\right)\end{array}$ & $\begin{array}{c}\text { Horas de } \\
\text { Lixiviação }\end{array}$ & $\begin{array}{c}\text { Densidade } \\
\text { Real } \\
\left(\mathrm{g} / \mathbf{c m}^{3}\right)\end{array}$ \\
\hline \multirow{4}{*}{3,38} & 24 & 3,39 & 24 & 3,43 & 24 & 3,42 \\
\hline & 56 & 3,49 & 56 & 3,44 & 56 & 3,41 \\
\hline & 96 & 3,42 & 96 & 3,40 & 96 & 3,41 \\
\hline & 120 & 3,35 & 120 & 3,35 & 120 & 3,37 \\
\hline
\end{tabular}




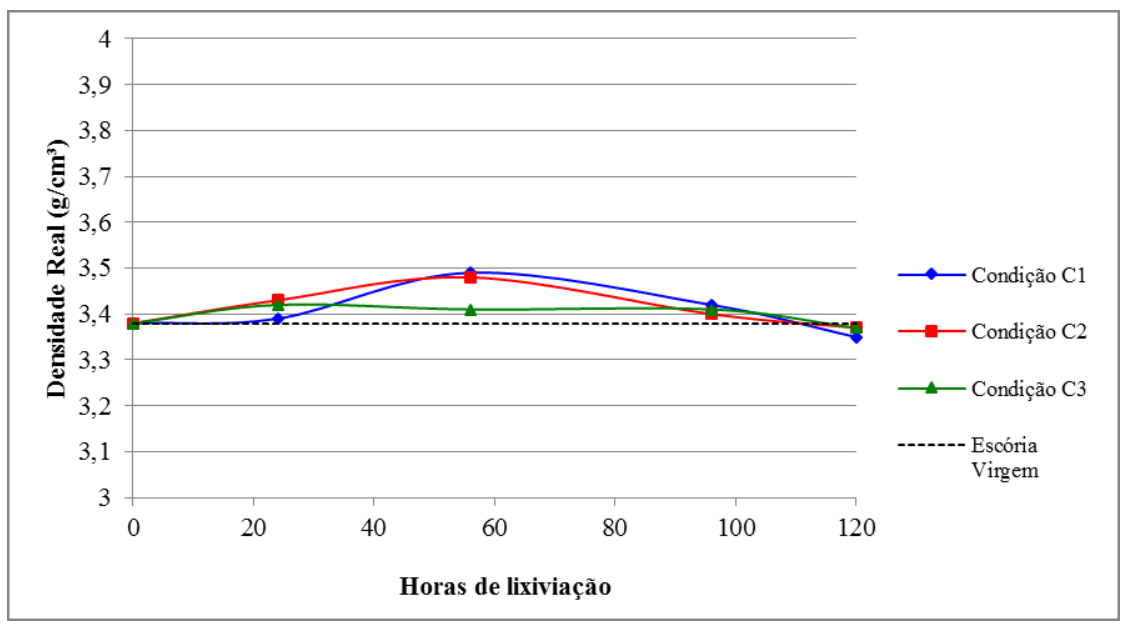

Figura 12: Gráfico de densidade real em função do tempo de lixiviação.

Diante dos resultados foi observado que não houve variação significativa nos valores de densidade real após as horas de lixiviação e nas condições analisadas (C1, C2 e C3). Os valores de densidade real encontrados nesta pesquisa são compatíveis com outros estudos. Silva [30] encontrou valor médio de densidade real para escória de aciaria estabilizada de $3,27 \mathrm{~g} / \mathrm{cm}^{3}$. Tavares [34] utilizou agregado desta mesma empresa deste estudo e encontrou valores de densidade de $3,39 \mathrm{~g} / \mathrm{cm}^{3}$ para escória estabilizada. $\mathrm{O}$ estudo de Jia-chen $\mathrm{Xi}$ et al [23] apresentou valores de densidade relativa entre 3,3 e $3,5 \mathrm{~g} / \mathrm{cm}^{3}$.

Os resultados de densidade aparente são apresentados na Tabela 3 e Figura 13.

Tabela 3: Variação da densidade aparente do agregado de escórias em função do tempo de lixiviação.

\begin{tabular}{c|c|c|c|c|c|c}
\hline $\begin{array}{c}\text { Densidade } \\
\text { Aparente da } \\
\text { escória de aci- } \\
\text { aria virgem } \\
\left(\mathbf{g} / \mathbf{c m}^{\mathbf{3}}\right)\end{array}$ & \multicolumn{2}{|c|}{$\mathbf{C}$ - Lixiviado Superior } & \multicolumn{2}{c|}{$\mathbf{C 2}$ - Lixiviado Intermediário } & \multicolumn{2}{c}{$\mathbf{C 3}$ - Lixiviado Fundo } \\
\cline { 2 - 7 } & $\begin{array}{c}\text { Horas de } \\
\text { Lixiviação }\end{array}$ & $\begin{array}{c}\text { Densidade } \\
\text { Aparente } \\
\left(\mathbf{g} / \mathbf{c m}^{\mathbf{3}}\right)\end{array}$ & $\begin{array}{c}\text { Horas de } \\
\text { Lixiviação }\end{array}$ & $\begin{array}{c}\text { Densidade } \\
\text { Aparente } \\
\left(\mathbf{g} / \mathbf{c m}^{\mathbf{3}}\right)\end{array}$ & $\begin{array}{c}\text { Horas de } \\
\text { Lixiviação }\end{array}$ & $\begin{array}{c}\text { Densidade } \\
\text { Aparente } \\
\left(\mathbf{g} / \mathbf{c m}^{\mathbf{3}} \mathbf{)}\right.\end{array}$ \\
\hline \multirow{3}{*}{3,00} & 24 & 3,05 & 24 & 3,08 & 24 & 3,10 \\
& 56 & 3,13 & 56 & 3,07 & 56 & 3,08 \\
& 96 & 3,05 & 96 & 3,07 & 96 & 3,07 \\
& 120 & 2,96 & 120 & 2,98 & 120 & 3,03 \\
\hline
\end{tabular}

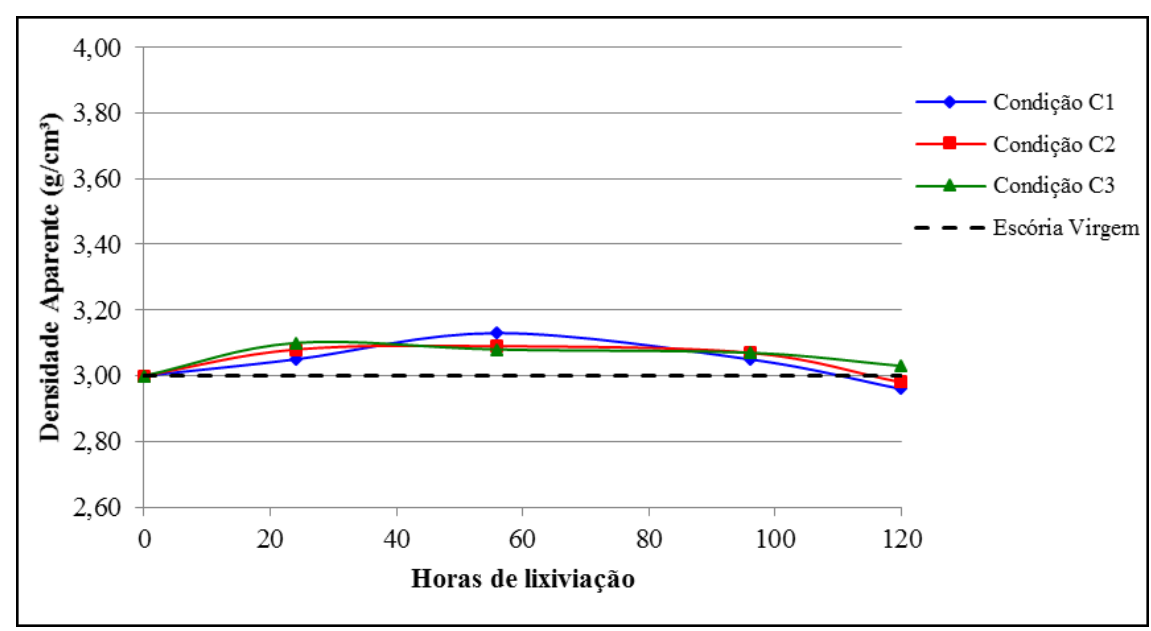

Figura 13: Gráfico de densidade aparente em função do tempo de lixiviação. 
Nos resultados de densidade aparente também se verifica pequena variação. A diferença nos valores encontrados de densidade aparente também pode estar associada à própria condição do ensaio e por manuseio do operador, e não tem relação com o processo de lixiviação propriamente dito.

Na Tabela 4 e Figura 14 apresentam a absorção da escória de aciaria após lixiviação em todos os períodos (24, 56, 96 e 120 horas) e nas três condições (C1, C2 e C3) dentro do extrator do equipamento Soxhlet.

Tabela 4: Variação da absorção do agregado de escórias em função do tempo de lixiviação.

\begin{tabular}{c|c|c|c|c|c|c}
\hline $\begin{array}{c}\text { Absorção da } \\
\text { escória de } \\
\text { aciaria vir- } \\
\text { gem (\%) }\end{array}$ & \multicolumn{2}{c|}{ C1 - Lixiviado Superior } & \multicolumn{2}{c|}{ C2 - Lixiviado Intermediário } & \multicolumn{2}{c}{ C3 - Lixiviado Fundo } \\
\cline { 2 - 7 } & \begin{tabular}{c} 
Lixiviação \\
\multirow{3}{*}{}
\end{tabular} & $\begin{array}{c}\text { Absorção } \\
\text { (\%) }\end{array}$ & $\begin{array}{c}\text { Horas de Lixi- } \\
\text { viação }\end{array}$ & $\begin{array}{c}\text { Absorção } \\
(\%)\end{array}$ & $\begin{array}{c}\text { Horas de } \\
\text { Lixiviação }\end{array}$ & $\begin{array}{c}\text { Absorção } \\
\text { (\%) }\end{array}$ \\
\hline 3,5 & 24 & 3,34 & 24 & 3,30 & 24 & 3,03 \\
& 56 & 3,33 & 56 & 3,57 & 56 & 3,15 \\
& 96 & 3,57 & 96 & 3,30 & 96 & 3,19 \\
& 120 & 3,86 & 120 & 3,47 & 120 & 3,59 \\
\hline
\end{tabular}

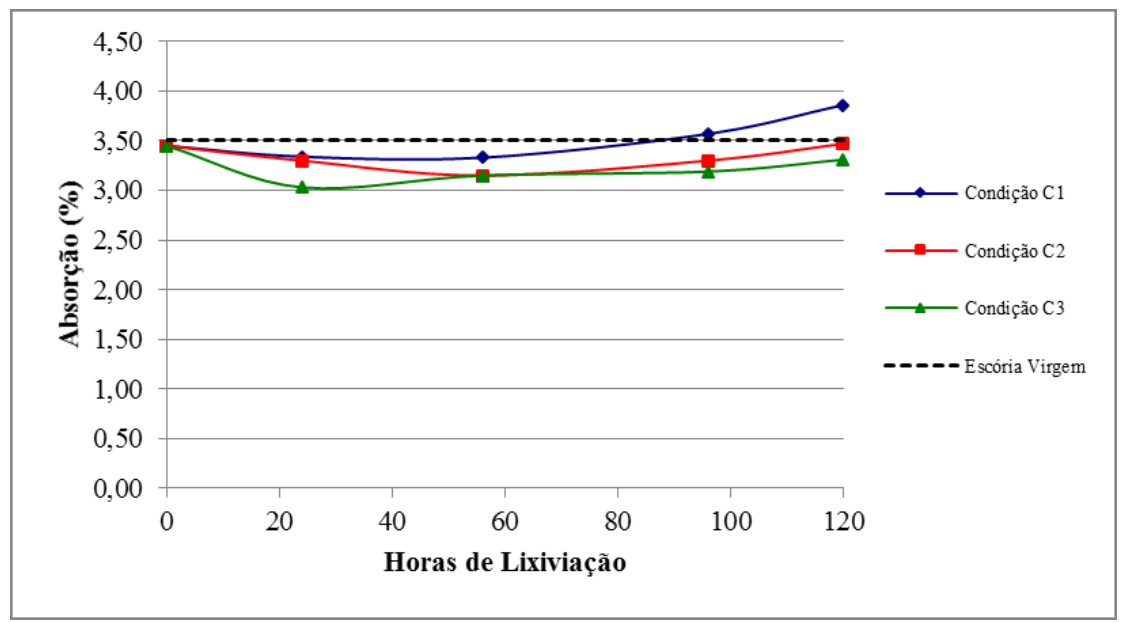

Figura 14: Gráfico de absorção em função do tempo de lixiviação.

Foi possível perceber na Tabela 4 uma pequena variação nos valores de absorção. Nas condições C1 (maior temperatura) e C3 (material sempre submerso) onde ocorreram as condições extremas de lixiviação, foram observados os maiores valores de absorção de 3,86\% e 3,59\%, respectivamente.

Na Figura 14 é observado um pequeno aumento na absorção do material ao final das 120 horas de lixiviação em extrator Soxhlet em relação à escória virgem. Entretanto, este aumento é considerado pequeno (um aumento inferior a 10\%) e podem estar associados ao processo de lixiviação devido à expansão do material, mas também podem ser relacionados à reprodutibilidade do ensaio.

Os valores encontrados para a absorção na escória lixiviada são superiores ao estabelecido pela norma, de maneira análoga a absorção da escória de aciaria virgem.

Na Tabela 5 e Figura 15 são apresentados os resultados da perda ao choque em aparelho Treton após lixiviação em todos os períodos $(24,56,96$ e 120 horas) e nas três condições $(C 1, C 2$ e C3) dentro do extrator do equipamento Soxhlet. 
Tabela 5: Variação do ensaio de impacto Treton do agregado de escórias em função do tempo de lixiviação.

\begin{tabular}{c|c|c|c|c|c|c}
\hline \multirow{2}{*}{$\begin{array}{c}\text { Escória de } \\
\text { Aciaria }\end{array}$} & \multicolumn{2}{|c|}{ C1 - Lixiviado Superior } & \multicolumn{2}{c|}{ C2 - Lixiviado Intermediário } & \multicolumn{2}{c}{ C3 - Lixiviado Fundo } \\
\cline { 2 - 7 } Virgem (\%) & $\begin{array}{c}\text { Dias de } \\
\text { Lixiviação }\end{array}$ & $\begin{array}{c}\text { \% Perda } \\
\text { Treton }\end{array}$ & $\begin{array}{c}\text { Dias de } \\
\text { Lixiviação }\end{array}$ & $\begin{array}{c}\text { \% Perda } \\
\text { Treton }\end{array}$ & $\begin{array}{c}\text { Dias de } \\
\text { Lixiviação }\end{array}$ & $\begin{array}{c}\text { \% Perda } \\
\text { Treton }\end{array}$ \\
\hline \multirow{4}{*}{8,31} & 24 & 3,23 & 24 & 4,98 & 24 & 2,85 \\
& 56 & 3,18 & 56 & 4,30 & 56 & 5,01 \\
& 96 & 5,08 & 96 & 5,99 & 96 & 8,79 \\
& 120 & 11,85 & 120 & 7,66 & 120 & 6,42 \\
\hline
\end{tabular}

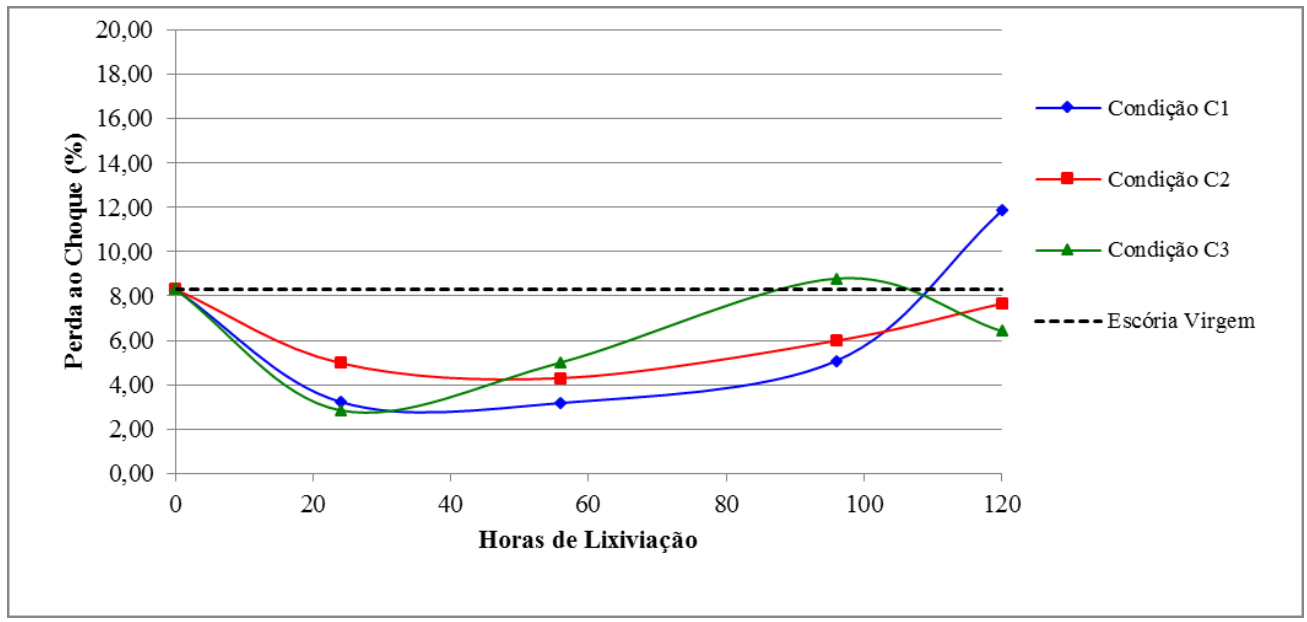

Figura 15: Gráfico de impacto Treton em função do tempo de lixiviação.

Na Figura 15 é possível observar que a perda ao choque inicialmente diminui, a partir das primeiras horas de lixiviação, mas apresenta nítida tendência de crescimento para horas mais alongadas. Tal tendência confirma que a lixiviação tem influência sobre a perda de resistência do material quando este é exposto principalmente às elevadas temperaturas e a contato direto com a precipitação como ocorre na condição $\mathrm{C} 1$ após 120 horas de lixiviação.

Os valores obtidos de perda ao choque ficaram abaixo do limite estabelecido na DNER-ME 399 [17] que é de $60 \%$, isso indica a elevada resistência da escória de aciaria apesar das condições severas de lixiviação.

A Tabela 6 apresenta a perda de massa obtida no ensaio de durabilidade, realizado com a escória de aciaria após lixiviação considerando-se os períodos (24, 56, 96 e 120 horas). Neste caso foi realizado o ensaio apenas com o material passante na peneira de $12,7 \mathrm{~mm}$ e retido na $9,5 \mathrm{~mm}$, com massa de aproximadamente 330 gramas conforme norma [11]. Essa adaptação na norma DNER ME 089 [11] foi necessária, devido à quantidade de material lixiviado em extrator Soxhlet ser restrita.

Tabela 6: Perda de massa por durabilidade das amostras lixiviadas nos períodos analisados.

\begin{tabular}{c|c|c}
\hline Escória de aciaria Virgem (\%) & Horas de lixiviação & \% de perda \\
\hline & 24 & 1,30 \\
\multirow{2}{*}{4,4} & 56 & 4,50 \\
& 96 & 0,52 \\
& 120 & 2,54 \\
\hline
\end{tabular}


$\mathrm{Na}$ Tabela 6 é possível perceber que a perda de massa por durabilidade atendeu em todos os períodos de lixiviação tanto a norma de agregado convencional com máximo de perda de $12 \%$ quanto para a norma de escória de aciaria DNER ES 262 [12] de com perda máxima até 5\%.

Apesar de satisfazer os critérios adotados em norma técnica, estes resultados estão longe de ser desprezíveis, haja vista uma perda de massa na ordem de 4,5\% - observada no caso de 56 horas de lixiviação pode significar importante perda de propriedades físicas e mecânicas do agregado.

Entretanto, não se pode afirmar, a partir dos dados da Tabela 6, que há uma relação entre o tempo de lixiviação e a perda de massa no ensaio de durabilidade, sendo esta dispersão atribuída à heterogeneidade do material.

As amostras lixiviadas foram encaminhadas para ensaio em microscópio eletrônico de varredura MEV a fim de verificar sua estrutura superficial por meio de imagem de alta resolução. Devido ao tamanho da cápsula do equipamento foi possível apenas a análise de partículas menores que 4,75 mm. Para cada período (24, 56, 96 e 120 horas) foi gerada uma imagem representando sua microestrutura. As Figuras 16 e 17 apresentam a micrografia da escória de aciaria lixiviada a cada período.
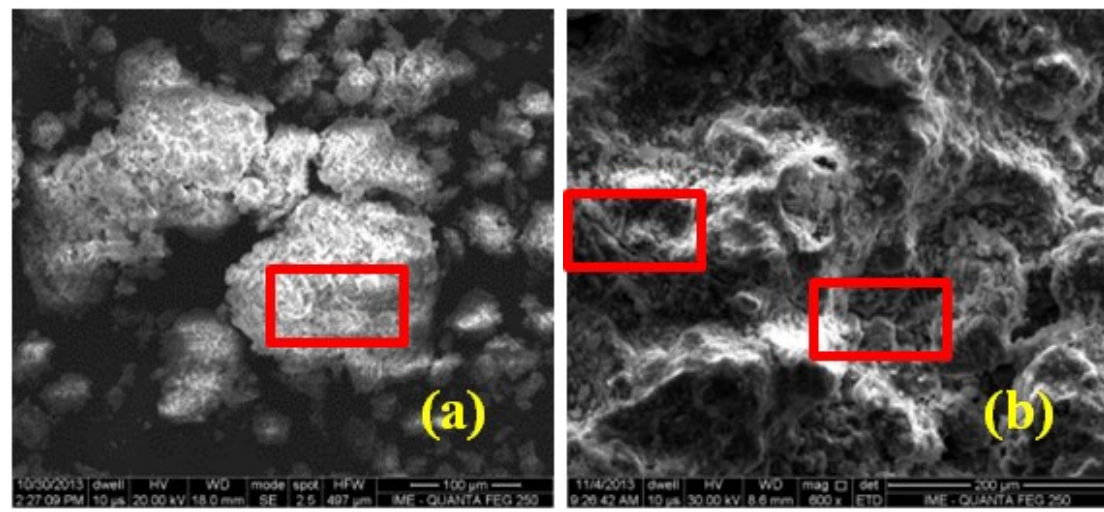

Figura 16: Micrografia da escória de aciaria estudada: (a) 24 horas e (b) 56 horas.
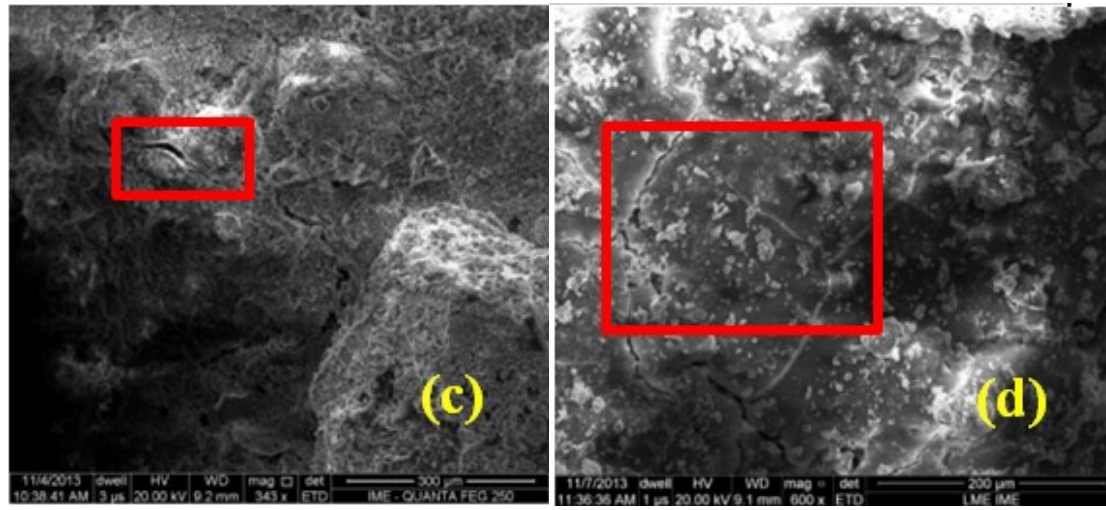

Figura 17: Micrografia da escória de aciaria estudada: (c) 96 horas e (d) 120 horas.

A partir das Figuras 16 e 17 foi observado que com o aumento das horas de lixiviação, a microestrutura da escória de aciaria estudada nesta pesquisa apresentou-se com maior padrão de trincamento. Esse fenômeno era esperado devido ao processo de expansão da escória.

Os ensaios de EDS e difração de raios-X da escória de aciaria lixiviada foram realizados para verificar a variação dos componentes químicos e mineralógicos mais comuns presentes na amostra virgem. A Figura 18 apresenta o gráfico de $\mathrm{CaO}$ presente na escória de aciaria lixiviada após cada período e cada condição em estudo. 


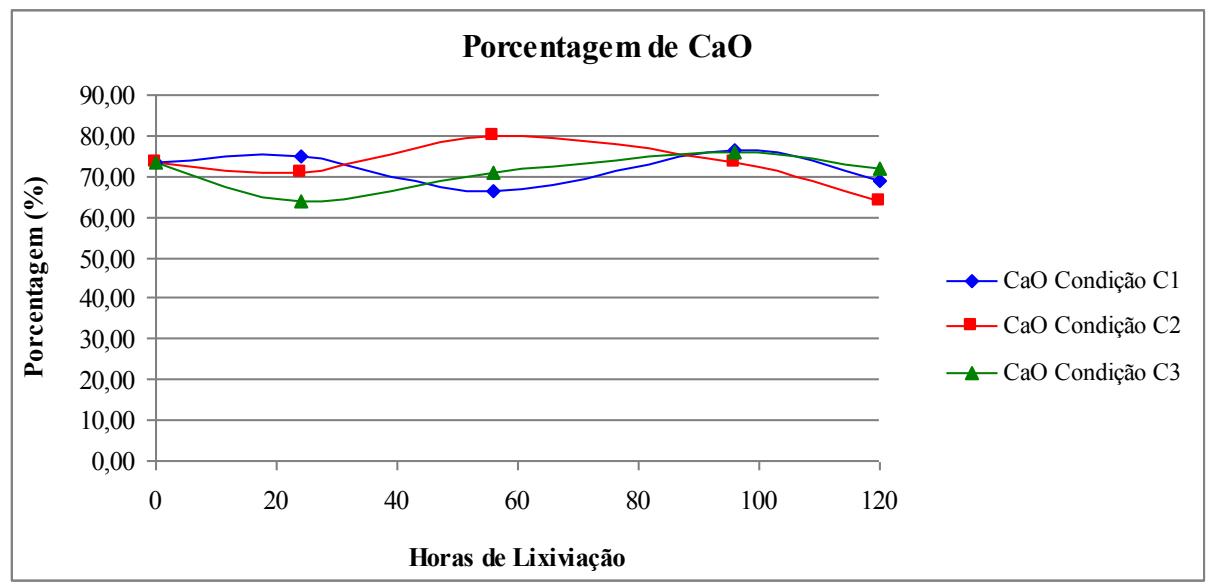

Figura 18: Teor de $\mathrm{CaO}$ no agregado de escória de aciaria lixiviado após cada período de lixiviação.

Foi possível observar que houve variação na porcentagem de $\mathrm{CaO}$ dos agregados lixiviados e pode-se observar uma pequena diminuição nos teores ao longo do tempo, entretanto, não pode estabelecer uma tendência no comportamento do $\mathrm{CaO}$ após a lixiviação em extrator Soxhlet. Como não houve variação significativa dos demais componentes químicos, foi apresentado somente do $\mathrm{CaO}$.

A difração de raios-X comprovou a existência de estruturas cristalinas formadas por $\mathrm{Ca}, \mathrm{Fe}$ e $\mathrm{Si}$, mesmas estruturas observadas na escória de aciaria virgem. A Figura 19 apresenta a difração de raios-X da amostra lixiviada.

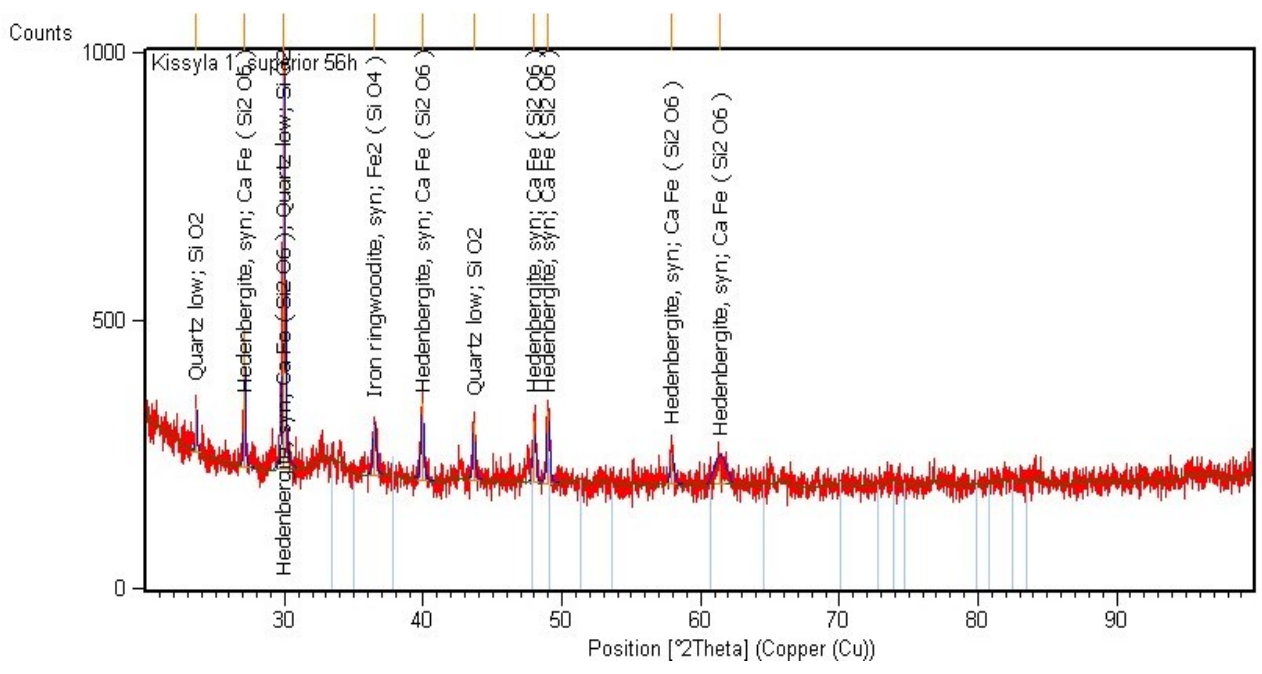

Figura 19: Exemplos de estruturas cristalinas encontradas na escória de aciaria lixiviada em todos os períodos.

Com relação à expansão, a escória virgem apresentou valor de expansão de 1,4\% quando medida com o cilindro de Mini-MCV com $49 \mathrm{~mm}$ de diâmetro e com material com $49 \mathrm{~mm}$ de altura. Os ensaios de expansão para as escórias de aciaria lixiviadas foram realizados apenas no intuito de verificar se a escória de aciaria seria ou não expansiva após submetida a vários dias de lixiviação em extrator Soxhlet. Não foi possível estabelecer uma tendência na redução do potencial de expansão após os períodos de lixiviação, devido a este ser baixo na escória de aciaria virgem. Entretanto, pode-se constatar uma redução no potencial de expansão após lixiviação.

Os resultados do potencial de expansão da escória de aciaria lixiviada a cada período (24, 56, e 120 horas) e para cada condição (C1, C2 e C3) são apresentados nas Figuras 20, 21 e 22. 


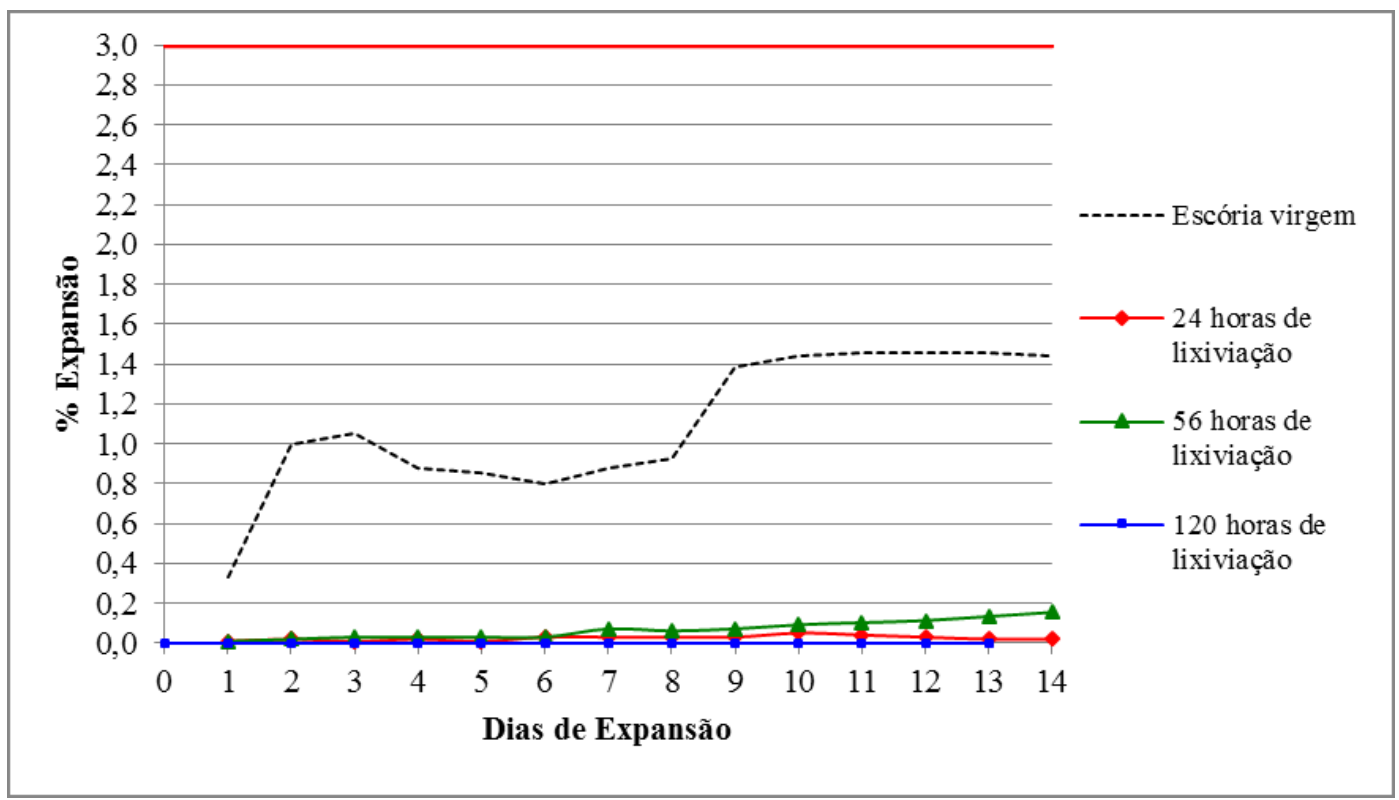

Figura 20: Potencial de expansão para a condição $\mathrm{C} 1$ em cada período de lixiviação.

Na Figura 20 é possível perceber que na condição C1 - parte superior do equipamento Soxhlet - houve redução significativa no potencial de expansão após os dias de lixiviação. No período de 24 horas de lixiviação a porcentagem de expansão foi de $0,021 \%$, no período de 56 horas foi de $0,15 \%$ e após 120 horas de lixiviação o valor observado foi de $0 \%$. Não foi possível realizar o ensaio de expansão no período de 96 horas. No entanto, é observada uma redução no decorrer dos dias de lixiviação.

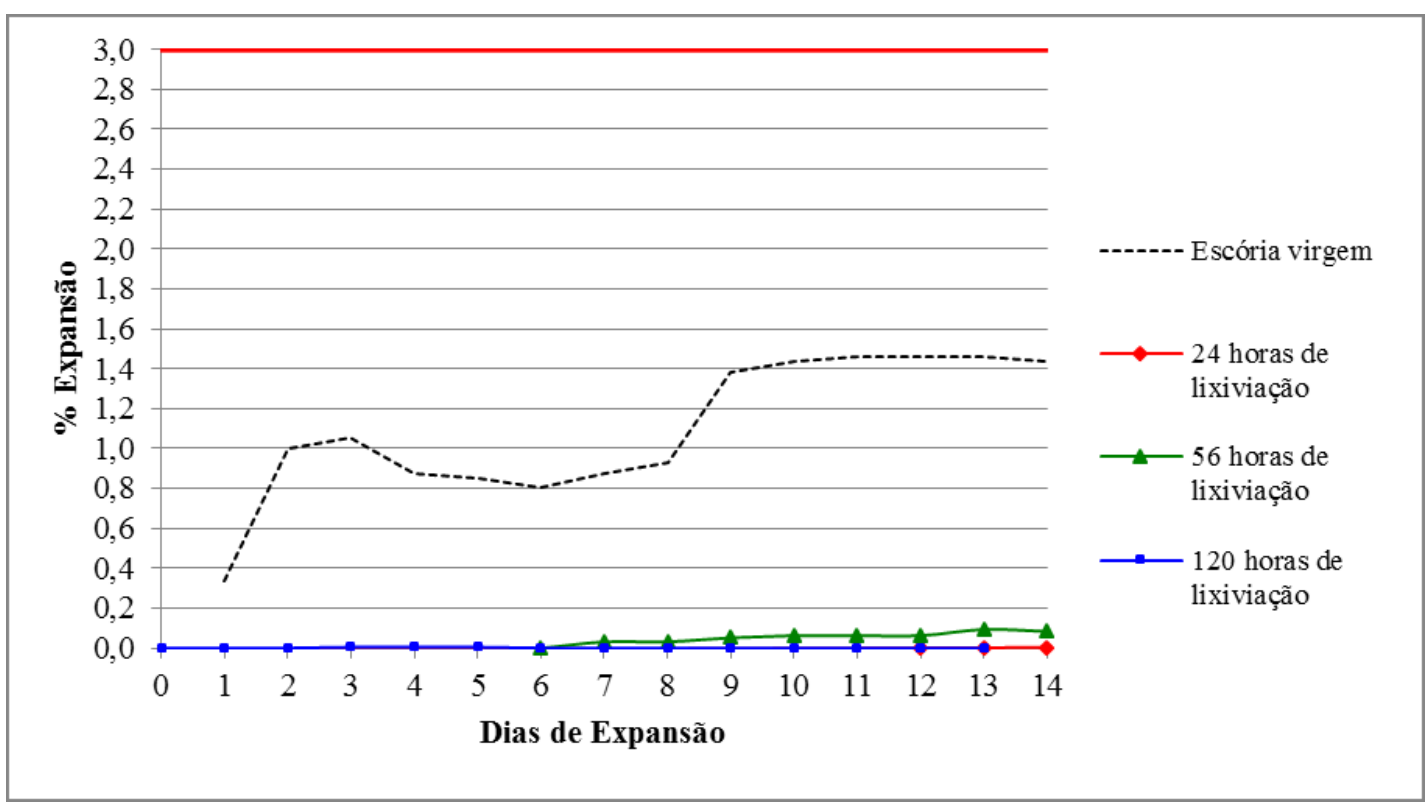

Figura 21: Potencial de expansão para a condição C2 em cada período de lixiviação.

Da mesma forma como para a condição C1, é observado (Figura 21) que na condição C2 - parte intermediária do equipamento Soxhlet - houve redução significativa no potencial de expansão após os dias de lixiviação. No período de 24 horas de lixiviação a porcentagem de expansão foi de $0,003 \%$, no período de 56 horas foi de $0,083 \%$ e após 120 horas de lixiviação o valor observado foi de $0 \%$. Não foi possível realizar ensaio de expansão no período de 96 horas. Pode-se constatar também que a redução de potencial de expansão foi mais severa na condição $\mathrm{C} 2$ quando comparada a condição $\mathrm{C} 1$ 


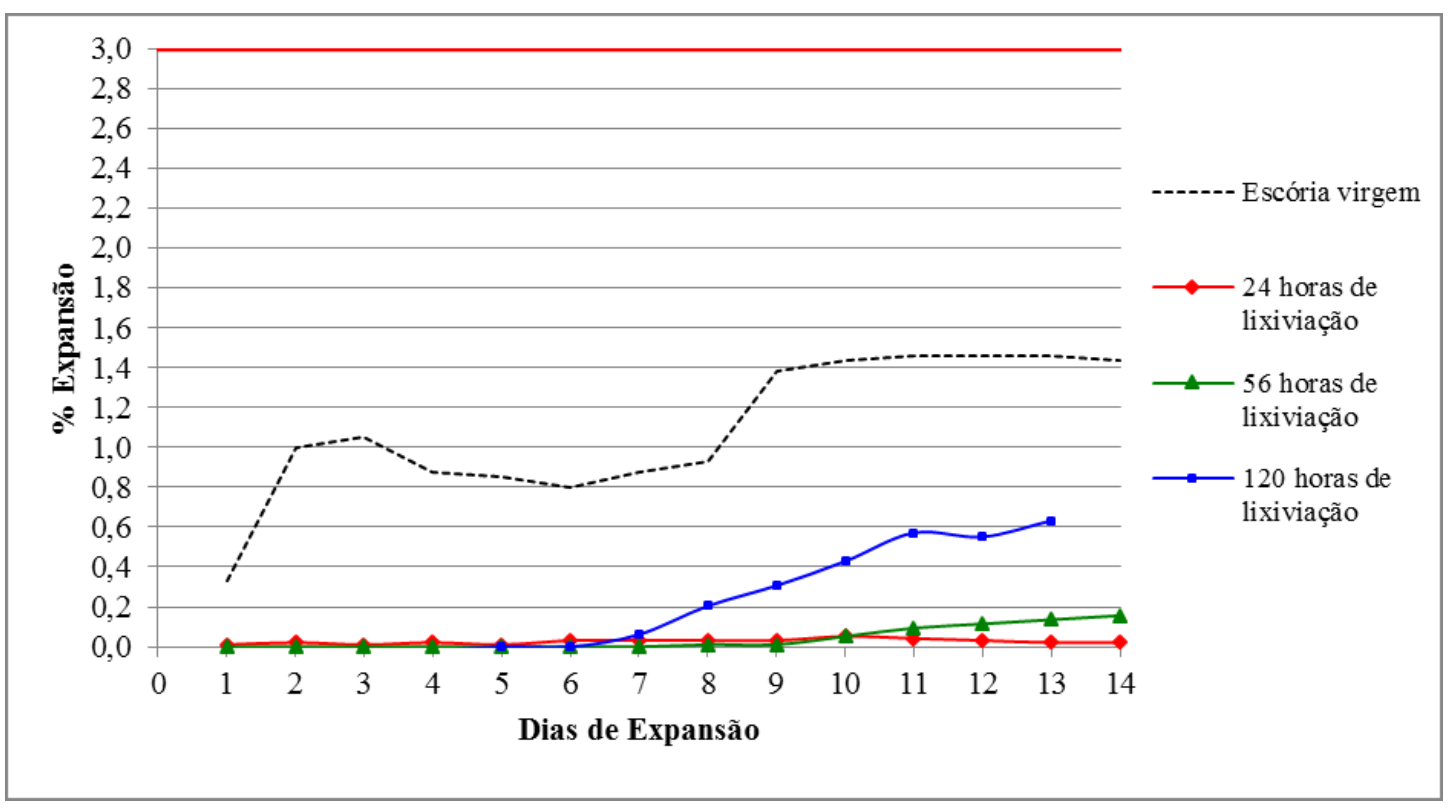

Figura 22: Potencial de expansão para a condição C3 em cada período de lixiviação.

Na Figura 22 apesar de ocorrer a redução no potencial expansivo da escória de aciaria na condição C3 é possível verificar que a redução do mesmo não é tão severa quanto a observada nas condições $\mathrm{C} 1$ e $\mathrm{C} 2$, uma vez que o material se encontra no fundo do equipamento Soxhlet e em temperaturas mais baixas. Essa diferença ressalta que o material não necessita ficar em submersão em água para que ocorra a diminuição no potencial expansivo. No período de 24 horas de lixiviação a porcentagem de expansão foi de $0,021 \%$, no período de 56 horas foi de $0,15 \%$ e após 120 horas de lixiviação o valor observado foi de $0,63 \%$. Não foi possível realizar o ensaio de expansão no período de 96 horas.

Apesar de a escória de aciaria virgem já apresentar um percentual de expansão baixo de 1,4\% é possível concluir que o processo de lixiviação contínua em extrator Soxhlet teve influência sobre esse percentual. De acordo com o observado nos três gráficos verificou-se que todos os valores estão abaixo do valor limite de 3\% normatizado pela DNER 262 [12], sendo possível perceber claramente a redução do potencial de expansão da escória em função do processo de lixiviação controlada em laboratório com equipamento Soxhlet.

\section{CONCLUSÕES}

Após a análise das variações das propriedades da escória de aciaria lixiviada conclui-se que o processo de lixiviação deste estudo em escória de aciaria não teve influência significativa sobre as propriedades físicas. Contudo, em se tratando de suas características microestruturais, químicas e expansivas o processo de lixiviação mostrou-se de suma importância, uma vez que acelera a estabilização dos componentes presentes na escória de aciaria e gera ao agregado características que permitem sua utilização em obras de pavimentação.

O processo de lixiviação controlada em laboratório simulou bem o processo de intemperismo químico que ocorre no pátio de beneficiamento da escória de aciaria. A precipitação da água da chuva e a elevação da temperatura no decorrer do tempo provocam a estabilização dos componentes responsáveis pelo processo expansivo da escória. Este processo ocorre naturalmente, porém, demandam de longos períodos.

O processo de lixiviação desenvolvido em laboratório reduziu este tempo simulando a aspersão da água na escória de aciaria em temperatura controlada sem prejudicar as propriedades físicas do agregado, mas reduzindo o potencial expansivo. Este processo atrelado às adequações no beneficiamento da escória de aciaria pode aumentar a viabilidade técnica e econômica na utilização da escória de aciaria em obras rodoviárias, bem como reduzir um passivo ambiental.

É sugerido estudo com escórias com potencial de expansão que não atenda aos requisitos determinados pelo DNIT para que se tenha uma maior compreensão do processo de lixiviação em escórias de aciaria com alto teor de expansão, também sugere-se a aplicação do material lixiviado em misturas asfálticas para verificação do comportamento do mesmo. 


\section{AGRADECIMENTOS}

Agradeço primeiramente a Deus e aos meus pais. Agradeço aos meus orientadores pela amizade, carinho e apoio. Aos funcionários do IME, pela colaboração. A Harsco Metals pelo apoio para a realização deste trabalho. A CAPES e ao Instituto Militar de Engenharia pela oportunidade da formação acadêmica de excelência.

\section{BIBLIOGRAFIA}

[1] ABM - Associação Brasileira de Metalurgia e Metais. "Estudo prospectivo do setor siderúrgico: 2008". Caderno de Informações de Base. Centro de Gestão e Estudos Estratégicos, Brasília, 2008.

[2] ABNT - Associação Brasileira de Normas Técnicas, CB-018: Cimento, Concreto e Agregados. Agregados para concreto - Especificação, 2009.

[3] ALVES, J.O. Processo de reciclagem da escória de aciaria e do resíduo de corte do granito visando a produção de lã mineral. Dissertação de M. Sc., Rede Temática em Engenharia de Materiais - UFOP, Minas Gerais, 2008.

[4] AHMEDZADE, P., SENGOZ, B. "Evaluation of steel slag coarse aggregate in hot mix asphalt concrete", Journal of Hazardous Materials, v.165, pp. 300-305, 2009.

[5] ASTM D 4792- American Society For Testing And Materials - Potential Expansion of Aggregates from Hydration Reactions, 2000.

[6] ASTM D 4940 - American Society For Testing And Materials -Standard Specification for Graded Aggregate Material For Bases or Sub-bases for Highways or Airports, 2003.

[7] BALTAZAR, R. P. Caracterização do fator expansão de uma escória de aciaria em diferentes processos de cura para uso em pavimentação, Dissertação de M. Sc., UFV,Viçosa, 2001.

[8] CAMPOS, A. A. Desenvolvimento de escória sintética sintetizada para a produção de aços elétricos de grão orientado (GO), Dissertação de M. Sc., Universidade Federal de Minas Gerais. Belo Horizonte, 2009.

[9] CASTELO BRANCO, V. T. F. Caracterização de Misturas Asfálticas com o Uso de Escória de Aciaria como Agregado, Dissertação de M.Sc., COPPE/UFRJ, Rio de Janeiro, 2004.

[10] CHESNER, W. H., COLLINS, R. J., MACKAY, M. H., et al., User guidelines for waste and by-product materials in pavement construction. FHA - Federal Highway Administration, U. S. Department of Transportation. http://trid.trb.org/view.aspx?id=483842 Acessado em 19 de dezembro de 2013.

[11] DNER ME 089. Agregado - Avaliação da Durabilidade pelo Emprego de Solução de Sulfato de Sódio ou Magnésio. Departamento Nacional de Estradas de Rodagem,1994.

[12] DNER EM 262. Escória de Aciaria para Pavimento Rodoviário. Departamento Nacional de Estradas de Rodagem. 1994.

[13] DNER - Departamento Nacional de Estradas de Rodagem. ME 113, Pavimentação rodoviária - Agregado artificial - Avaliação do potencial de expansão de escória de aciaria - Método de ensaio, 1997.

[14] DNER ME 035. Agregados - Determinação da Abrasão Los Angeles. Departamento Nacional de Estradas de Rodagem, 1998.

[15] DNER ME 081. Agregados - Determinação da Absorção e da Densidade do Agregado Graúdo. Departamento Nacional de Estradas de Rodagem, 1998.

[16] DNER ME 083. Agregados - Análise Granulométrica. Departamento Nacional de Estradas de Rodagem, 1998.

[17] DNER ME 399. Agregados - Determinação da Perda ao Choque no Aparelho Treton. Departamento Nacional de Estradas de Rodagem, 1999.

[18] DNIT - Departamento Nacional de Infraestrutura de Transporte. Mistura asfáltica- Determinação da porcentagem de betume em mistura asfáltica utilizando o extrator Soxhletm, 2009.

[19] FREITAS, H. B.; MOTTA, L. M. G. "Uso de escória de aciaria em misturas asfálticas de módulo elevado", Revista Transportes, v. XVII, n. 2, pp. 5-12, 2008.

[20] GEYER, R. M. T. Estudo sobre a Potencialidade de Uso das Escórias de Aciaria como Adição ao Concreto.Tese de D.Sc., PPGEM/UFRGS, Porto Alegre, 2001.

[21] HECK, N. C. Metalurgia Extrativa dos Metais Não-Ferrosos I-A. UFRGS/DEMET.

[22] JANE, P. Química Orgânica Experimental II. UFAM, http://www.ebah.com.br/content/ABAAABaFUAC/relatorio-extracao-continua\#. Acessado em: 06 de março 
de 2014.

[23] XI, J.C., XIANG, X.D., LI, C.H., et al. "Process improvement on the gradation uniformity of steel slag asphalt concrete aggregate", Procedia Environmental Sciences, v. 31, pp. 627- 634. 2016.

[24] MANSUERO, A. B. Estabilização da escória de aciaria elétrica com vistas a sua utilização como substituição ao cimento. Tese de D.Sc. Universidade Federal do Rio Grande do Sul. Porto Alegre. 2001.

[25] MARCACCINI, G. C. S. Estudo experimental de laboratório para emprego da escória de aciaria como agregado em camadas de base de pavimento flexivel. Trabalho de Conclusão de Curso de Engenharia Civil da Universidade Federal de Santa Catarina, Florianópolis, 2009.

[26] PEDROSA, R. A. A. Estudo da viabilidade técnica e econômica do uso de agregado de escória de aciaria em concreto betuminoso usinado a quente. Dissertação de M. Sc., Programa de Pós-Graduação em Engenharia Geotécnica - UFOP, Minas Gerais, 2010.

[27] ROHDE, L. Escória de Aciaria Elétrica em Camadas Granulares de Pavimentos - Estudo Laboratorial. Dissertação de M.Sc., UFRGS, Porto Alegre, Brasil. 2002.

[28] SAADE, M. R. M., SILVA, M. G., SILVA, V. G. Aplicação da Análise do Ciclo de Vida na construção civil: discussão sobre alocação de impactos entre o aço e suas escórias, Revista de Pesquisa em Arquitetura e Construção, v. 1, n.6, UNICAMP, Campinas, 2011.

[29] SALVIANO, A. B. Avaliação de escória de aciaria para o controle e abatimento de drenagem ácida de mineração. Dissertação de M. Sc., Instituto de Ciências Exatas e Biológicas - UFOP, Ouro Preto, 2010.

[30] SILVA, C. N. P. Um estudo sobre a viabilidade da utilização de escória de aciaria LD em camadas de pavimentos. Dissertação de M. Sc. Instituto Militar de Engenharia, Rio de Janeiro, 2013.

[31] SILVA FILHO. A.F. Contribuição ao estudo do desempenho de concreto produzido com agregado graúdo de escória de ferro-cromo. Dissertação de M. Sc., Universidade Federal do Rio Grande do Sul, Porto Alegre, 2001.

[32] SHINZATO, M. C., HYPOLITO, R., BARBIERI, A. J., et al., Alteração experimental de rochas carbonáticas, Caverna das Perólas, Iporanga (SP), Revista do Instituto Geológico, v. 31, n.1/2, pp.23-34, São Paulo. 2010.

[33] SORLINI, S. SANZE NI, A., RONDI, L., et al. "Reuse of steel slag in bituminous paving mixtures", Journal of Hazardous Materials, v. 209-210, pp. 84- 91. 2012.

[34] TAVARES, D. S. Avaliação laboratorial de mistura asfáltica do tipo SMA com agregado siderúrgico. Dissertação de M. Sc. UFRJ/COPPE. Rio de Janeiro. 2012. 